\title{
Phytosociological Studies on Tree Species of Peddagattu and Sherepally Area, A Proposed Site for Uranium Mining Project, Nalgonda District, Telangana State, India
}

\author{
A. Baleeshwar Reddy ${ }^{1}$, V. Hanumanth Rao ${ }^{2}$, V. Vasudeva Rao ${ }^{2}$ \\ and A. Vijaya Bhasker Reddy ${ }^{1^{*}}$ \\ ${ }^{1}$ Department of Botany, University College of Science, Osmania University, Saifabad, Hyderabad- \\ 500 004, Telangana State. \\ ${ }^{2}$ AINP on Vertebrate Pest Management, Prof. Jayashankar Telangana State Agricultural \\ University, Rajendranagar, Hyderabad- 500030, Telangana State, India.
}

${ }^{*}$ Corresponding author e-mail: avijayabhaskerreddy@gmail.com

Keywords: IVI, Phytosocilology, Uranium project, Shannon-wiener index.

\begin{abstract}
The present study deals with the quantitative floristic inventory of Peddagattu and Sherepally area, Nalgonda district, Telangana State, India. The study resulted in documentation of 50 tree species belongs to 41 genera and 35 families. The families, Mimosaceae, Caesalpiniaceae and Fabaceae are dominated. Among the tree species Cassia fistula has showed highest IVI in Peddagattu, while in Sherepally Albizia amara has recorded highest IVI. Shannon-Wiener index $\left(\mathrm{H}^{\prime}\right)$ ranges from 2.41 to 3.03. The present study can serve as baseline information for phytosociolgical studies on tree species of Peddagattu and Sherepally area, a proposed site for Uranium mining project, Nalgonda district, Telangan State, India.
\end{abstract}

\section{INTRODUCTION}

According to the American Heritage Dictionary [1], Phytosociology means the study of characteristics, classification, relationships, and distribution of plant communities. According to many authors plant sociology or Phytosociology is a branch of science that deals with plant communities, their composition, evolution and the relationship between the constitute species. The quantitative study of vegetation is called Phytosociology and its principal aim is to describe vegetation and biodiversity in terms of numbers of species may decline [2, 3]. Phytosociology is used in many different research fields in nature conservation to describe the habitat and give the reader an idea of the species composition and vegetation structure. It is therefore important that vegetation description studies should be as comprehensive as possible [4].

With increase in human activity in and around forest ecosystems, Phytosociological analysis of natural vegetation is recognized as an efficient and appropriate method to select out useful plant species from natural communities. Modern scientific society uses Phytosociology either to form the background of scientific studies on animals $[5,6,7]$ or to define different plant communities, which could be unique in the sense of rare or endangered plant species occurrence and distribution [8, 9 , 10]. The present study was undertaken to determine the phytosociolgical studies on tree diversity in Peddagattu and Sherepally area, a proposed site for Uranium mining project in Nalgonda district, Telangana State, India.

\section{MATERIALS AND METHODS}

\section{Study area}

The study area is lying between $16^{\circ} 25^{\prime}$ to $17^{\circ} 00^{\prime} \mathrm{N}$ latitude and $78^{\circ} 40^{\prime}$ to $79^{\circ} 30^{\prime} \mathrm{E}$ longitude having an area of $10 \mathrm{~km}$ radius. The entire study area is divided into two core zones $(0-$ $5 \mathrm{~km}$ radius) named as Peddagattu Core zone which is a proposed site for uranium mining and Sherepally Core zone which is a proposed site for uranium processing followed by $5-30 \mathrm{~km}$ radius of buffer zone (Fig.1). 
The annual rainfall varies between 56 and $62 \mathrm{~cm}$ with the annual mean temperature is $34^{\circ} \mathrm{c}$. Physiographically the study area consists of flat topped hills composed of proterozoic sediments. The rocky exposures at the bottom of the hills generally are composed of granitic rocks. The general drainage pattern is dendritic indicating homogeneous nature of formations. The general elevation of the hills is about $300 \mathrm{~m}$ and the ground is $215 \mathrm{~m}$. Majority of the land area is under cultivation. The predominant crops raised in the area include rice, sorghum, cotton and chilies.

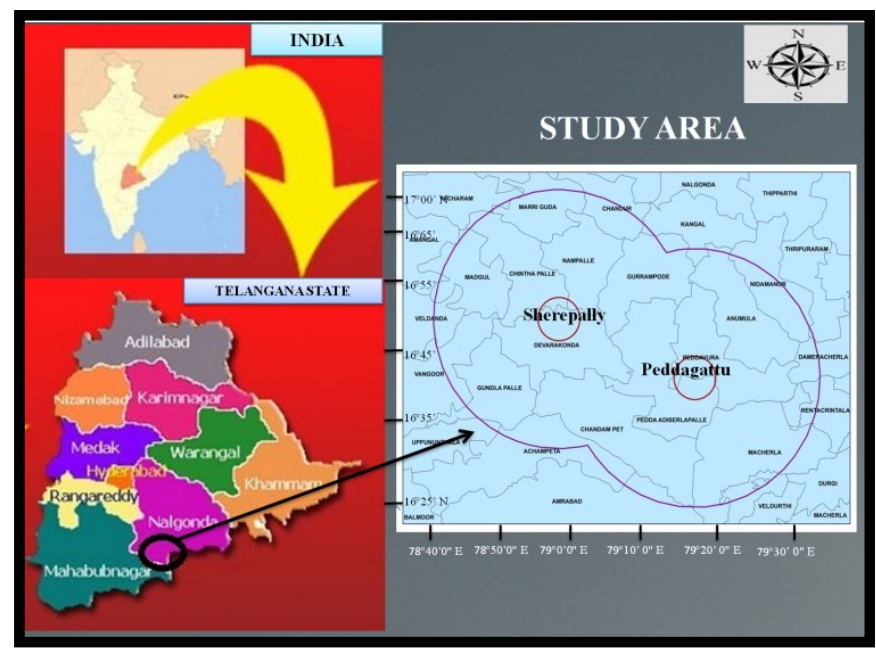

Fig 1: Study area with two core zones

\section{Methodology}

The study was carried out from April 2010 to December 2013 for period of 3 years. Randomly stratified 1139 quadrates were laid in $10 \mathrm{~km}$ radius in four directions and the analytical characters were recorded mostly by randomly stratified quadrate method. The quadrate size for trees, shrubs, and herbs was $10 \times 10 \mathrm{~m}, 5 \times 5 \mathrm{~m}$ and $1 \times 1 \mathrm{~m}$ respectively [11].

The specimens were identified from their key vegetative and reproductive features using the Flora of Nalgonda district [12], Flora of Guntur district [13] and Flora of the Presidency of Madras [14]. The plant species collected were processed and mounted on herbarium sheets. The collected species were pressed and deposited in Botanical survey of India, Deccan regional centre, Hyderabad.

\section{Data analysis}

All plant species recorded within each quadrate were indentified then counted and estimated their cover percentage. The phytosociological attributes: density, frequency and dominance and their relative value and important value index (IVI) were calculated according to the principles of Cottam and curties [15]. The following were the different parameters for calculation of relevant attributes.

$$
\text { Relative Density }=\frac{\text { Density of individuals of a species }}{\text { Total density of all species }} \times 100
$$

Relative Frequency $=$ Frequency of individuals of a species $\times 100$

Total frequency of all species

Relative Dominance $=$ Basal area of the species $\times 100$

Total basal area of the species 
Important Value Index (IVI) = Relative density + Relative frequency + Relative dominance

Shannon- Wiener Index (H') [16]:

$$
\begin{aligned}
& \mathrm{H}^{\prime}=-\sum_{\mathrm{i}=1}(\mathrm{pi} \text { In }(\mathrm{pi})) \quad(\text { with } \mathrm{i}=1 \text { to } \mathrm{S}) \\
& \mathrm{S}=\text { number of species or Species richness } \\
& \mathrm{N}=\text { Number of all individuals } \\
& \mathrm{ni}=\text { number of individuals in species } \mathrm{i} \\
& \mathrm{pi}=\text { the proportional of individuals in species (i) } \\
& \qquad(\mathrm{Pi}=\mathrm{ni} / \mathrm{N})
\end{aligned}
$$

Evenness: Evenness $\left(\mathrm{J}^{\prime}\right)$ was calculated from the ratio of observed diversity to maximum diversity [17] using the following equation.

$$
\mathrm{E}^{\prime}=\mathrm{H} / \mathrm{H}_{\max }=\mathrm{H} / \mathrm{In} s
$$

Where $\mathrm{H}_{\max }$ is the level of diversity possible within a given population, which equals in (number of species).

Simpson's Diversity Index [18] is calculated as followed.

$$
\begin{gathered}
\text { Simpson's index }=1-\chi \\
\left.\chi=\sum_{\mathrm{i}=1}^{\mathrm{S}} \frac{\text { ni (ni-1) }}{\mathrm{N}(\mathrm{N}-1)} \quad \text { (with } \mathrm{i}=1 \text { to } \mathrm{S}\right) \\
\mathrm{ni}=\text { The number of individuals in species (i) } \\
\mathrm{N}=\text { the total number of individuals in the sample }
\end{gathered}
$$

\section{RESULTS}

A total of 50 tree species belonging to 41 genera and 23 families were recorded in the study area. When the number of species, genera and families from the two sites analyzed separately, Peddagattu Core zone has higher share in all aspects (Table.1). In Peddagattu Core zone a total of 48 species were recorded with 22 families while in Sherepally Core zone the number of species are declined to 36 represent 18 families. The number of genera was decreased from 40 to 31 when we go from Peddagattu Core zone to Sherepally Core zone. Among the families Mimosaceae has showed highest number of species (10 species) followed by Caesalpiniaceae ( 9 species), Fabaceae (4 species), Ebenaceae, Moraceae, Myrtaceae, Rutaceae, Simarubaceae and Verbenaceae (2 species each). Peddagattu and Sherepally Core zones are dominated by Mimosaceae, Caesalpiniaceae and Fabaceae families.

Shannon diversity index was higher recorded at Peddagattu Core zone (3.03) than Sherepally Core zone (2.41). The average Shannon value in both areas contributes 2.7. Shannon diversity value exclusively depends on number of species recorded and number of individuals in study area. This clearly indicates that both the areas are representing with moderate to high species composition. Similarly the Evenness and Simpson diversity values are relatively higher at Peddagattu Core zone than Sherepally Core zone (Table.1). The species wise Relative density, relative frequency and relative dominance of both Core zones are given in Table 2 .

Based on importance value index (IVI), the top ten dominant species recorded in both sites are represented in Fig $2 \& 3$. Among the tree species, the highest IVI recorded at Peddagattu Core zone is for Cassia fistula (37.44), followed by Azadirachta indica (29.84), Chloroxylon swietenia (26.81), Acacia nilotica (24.23), Prosopis juliflora (20.06) and Ziziphus jujuba (18.92), while at Sherepally Core zone, Albizia amara (54.29) was recorded highest IVI followed by Prosopis juliflora (48.72), Azadirachta indica (40.51), Ziziphus jujuba (28.39) and Borassus flabellifer (27.5). 


\section{DISCUSSION}

A total of 50 species, 41 genera and 23families were recorded in two Core zones of Peddagattu and Sherepally. Species richness (36 - 48 species. $^{-1} a^{-1}$ ) and species diversity (2.72) of two sites are proportionally lower as compared to 185 tree species recorded in Tropical Forest of Similipal Biosphere reserve [19], 52-110 species $\mathrm{ha}^{-1}$ in Tropical forest in the Eastern Ghats of Northern Andhra Pradesh [20], 57 species $\mathrm{ha}^{-1}$ in Mylodai forest of Courtallum [21]. The Species richness recorded in the present study was higher than that of 43 species $^{\cdot} \mathrm{ha}^{-1}$ in Shervarayan hills [22]. The Shannon-Wiener index (H') value was 2.72, which is lower compared to 5.68 Shannon value of the Tropical forest in the Eastern Ghats [20] and 5 at the Tropical forest of Similipal Biosphere reserve [19].

In the present study a total of 23 families were recorded and most predominant families include Mimosaceae (10species), Caesalpiniaceae (9species) and Fabaceae (4 species). Similar results were observed at neo- tropical forests [23] and Shervarayan hills [22]. In Peddagattu Core zone, the species Cassia fistula and Chloroxylon swietenia and are showed highest IVI with higher number in forest area whereas compared to open areas. At Sherepally Core zone, Albizia amara, Prosopis juliflora, and Ziziphus jujuba were showed highest IVI. The tree species viz., Prosopis juliflora, Albizia amara and Ziziphus jujuba showed highe IVI values, it is due to dry climatic conditions and relatively a disturbed ecosystem. The species compositions of all regional levels directly or indirectly related to the variation of environmental factors [24] and disturbances [25].

\section{CONCLUSION}

The present study clearly showed that the moderate density of tree species in both study locations with dominant families Mimosaceae, Caesalpiniaceae and Fabaceae. Dominance of the species viz., Prosopis juliflora, Albizia amara, Cassia fistula, Chloroxylon swietenia, Azadirachta indica and Ziziphus jujuba are due to local environmental and habitat conditions. The study will certainly useful in future monitoring studies for enumerate the trends in composition of different families and the new establishments in the regions.

Table 1: Consolidated details of woody species inventory in Peddagattu and Sherepally area, Nalgonda district, Telangana State.

\begin{tabular}{|l|c|c|c|}
\hline \multicolumn{1}{|c|}{ Description } & Peddagattu & Sherepally & Total \\
\hline No. of tree species & 48 & 36 & 50 \\
\hline No. of genera & 40 & 31 & 41 \\
\hline No. of families & 22 & 18 & 23 \\
\hline Density & 3097 & 3206 & 6303 \\
\hline Species diversity (H') & 3.03 & 2.41 & 2.72 \\
\hline Evenness(J') & 0.52 & 0.43 & 0.46 \\
\hline Simpson index (D') & 0.76 & 0.58 & 0.65 \\
\hline
\end{tabular}

Table 2: Relative density (RD), relative frequency (RF), relative dominance (RDo) and Importance Value Index (IVI) of tree species of Peddagattu and Sherepally area.

\begin{tabular}{|c|l|c|c|c|c|c|c|c|c|}
\hline \multirow{2}{*}{ S. No } & \multirow{2}{*}{ Name of the species } & \multicolumn{3}{|c|}{ Peddagattu Core zone } & \multicolumn{3}{c|}{ Sherepally Core zone } \\
\cline { 3 - 11 } & & RD & RF & RDo & IVI & RD & RF & RDo & IVI \\
\hline 1 & Acacia auriculiformis Benth & 0.16 & 0.3 & 0.11 & 0.57 & - & - & - & - \\
\hline 2 & Acacia ferruginea DC. & 4.11 & 4.2 & 1.39 & 9.7 & 0.13 & 0.18 & 0.03 & 0.33 \\
\hline 3 & Acacia leucophloea (Roxb.) & 0.42 & 0.5 & 0.56 & 1.49 & 0.41 & 0.62 & 0.27 & 1.29 \\
\hline 4 & Acacia nilotica (L.) Delile & 3.75 & 8.09 & 12.39 & 24.23 & 5.67 & 8.39 & 11.47 & 25.53 \\
\hline 5 & Ailanthus excelsa Roxb & 0.1 & 0.2 & 0.4 & 0.7 & 0.63 & 1.24 & 1.52 & 3.38 \\
\hline
\end{tabular}




\begin{tabular}{|c|c|c|c|c|c|c|c|c|c|}
\hline 6 & $\begin{array}{l}\text { Alangium salviifolium (L.f.) } \\
\text { Wangerin }\end{array}$ & 0.29 & 0.5 & 0.07 & 0.87 & - & - & - & - \\
\hline 7 & Albizia amara (Roxb.) B.Boivin & 5.65 & 7.09 & 0.95 & 13.69 & 13.72 & 14.12 & 26.44 & 54.29 \\
\hline 8 & Albizia saman (Jacq.) Merr. & 1.14 & 1.1 & 4.82 & 7.06 & 0.09 & 0.09 & 0.1 & 0.29 \\
\hline 9 & Albizia lebbeck (L.) Benth. & 0.33 & 0.5 & 1.64 & 2.46 & 0.38 & 0.79 & 0.65 & 1.82 \\
\hline 10 & Annona squamosa $\mathrm{L}$. & 0.1 & 0.2 & 0.03 & 0.33 & 2.54 & 3.44 & 0.58 & 6.56 \\
\hline 11 & Azadirachta indica A.Juss. & 5.29 & 11.29 & 13.27 & 29.84 & 6.3 & 11.3 & 22.92 & 40.51 \\
\hline 12 & Balanites aegyptiaca (L.) Delile & 1.8 & 1.2 & 0.14 & 3.14 & 1.41 & 1.5 & 3.42 & 6.33 \\
\hline 13 & Bauhinia purpurea $\mathrm{L}$. & 0.13 & 0.1 & 0.19 & 0.42 & - & - & - & - \\
\hline 14 & Borassus flabellifer L. & 2.02 & 2.4 & 11.26 & 15.68 & 5.54 & 3.71 & 18.25 & 27.5 \\
\hline 15 & $\begin{array}{l}\text { Butea monosperma (Lam.) } \\
\text { Taub. }\end{array}$ & 1.63 & 1 & 2.13 & 4.76 & 0.41 & 0.35 & 0.38 & 1.14 \\
\hline 16 & Cassia fistula $\mathrm{L}$. & 12.7 & 8.79 & 15.95 & 37.44 & 2.29 & 3 & 0.52 & 5.81 \\
\hline 17 & Cassia roxburghii DC. & 0.2 & 0.4 & 0.15 & 0.74 & 0.06 & 0.18 & 0.06 & 0.3 \\
\hline 18 & Chloroxylon swietenia DC & 14.04 & 9.99 & 2.79 & 26.81 & 1.5 & 3.62 & 0.72 & 5.84 \\
\hline 19 & Citrus sinensis (L.) Osbeck (L.) & 7.05 & 3 & 6.32 & 16.37 & - & - & - & - \\
\hline 20 & Cordia dichotoma G.Forst & 0.03 & 0.1 & 0.07 & 0.2 & 0.06 & 0.09 & 0.15 & 0.3 \\
\hline 21 & Dalbergia sissoo DC. & 0.23 & 0.3 & 0.27 & 0.8 & 0.06 & 0.09 & 0.07 & 0.22 \\
\hline 22 & Delonix elata (L.) Gamble & - & - & - & - & 0.03 & 0.09 & 0.04 & 0.16 \\
\hline 23 & Delonix regia (Hook.) Raf. & 0.07 & 0.1 & 0.22 & 0.38 & - & - & - & - \\
\hline 24 & Diospyros chloroxylon Roxb. & 1.6 & 1.1 & 0.63 & 3.33 & - & - & - & - \\
\hline 25 & Diospyros melanoxylon Roxb. & 0.52 & 0.9 & 1.1 & 2.52 & - & - & - & - \\
\hline 26 & $\begin{array}{l}\text { Dolichandrone falcata (Wall. } \\
\text { ex DC.) Seem. }\end{array}$ & 1.53 & 1.5 & 2.43 & 5.46 & 2.16 & 2.38 & 0.44 & 4.98 \\
\hline 27 & Eucalyptus globulus Labill. & 0.49 & 0.2 & 0.42 & 1.11 & 1.06 & 0.79 & 0.23 & 2.08 \\
\hline 28 & Ficus benghalensis L. & 0.07 & 0.2 & 0.12 & 0.39 & 0.13 & 0.09 & 0.3 & 0.52 \\
\hline 29 & Ficus religiosa $\mathrm{L}$. & 0.13 & 0.3 & 0.37 & 0.8 & - & - & - & - \\
\hline 30 & Gliricidia sepium (Jacq.) Walp & 2.71 & 0.6 & 0.49 & 3.8 & 0.09 & 0.18 & 0.09 & 0.36 \\
\hline 31 & Grewia rotundifolia Juss. & - & - & - & - & 0.25 & 0.26 & 0.64 & 1.15 \\
\hline 32 & Hardwickia binata Roxb. & 4.54 & 3.4 & 1.66 & 9.59 & - & - & - & - \\
\hline 33 & $\begin{array}{l}\text { Holoptelea integrifolia (Roxb.) } \\
\text { Planch. }\end{array}$ & 1.31 & 2.1 & 1.91 & 5.32 & 4.35 & 6.71 & 1.82 & 12.89 \\
\hline 34 & $\begin{array}{l}\text { Leucaena leucocephala (Lam.) } \\
\text { de Wit }\end{array}$ & 0.46 & 0.6 & 0.29 & 1.35 & 0.38 & 0.53 & 0.17 & 1.07 \\
\hline 35 & Morinda pubescense Sm. & 0.23 & 0.3 & 0.16 & 0.69 & 0.03 & 0.09 & 0.01 & 0.13 \\
\hline 36 & Moringa oleifera Lam. & 0.07 & 0.1 & 0.06 & 0.22 & - & - & - & - \\
\hline 37 & Parkinsonia aculeata $\mathrm{L}$ & 0.07 & 0.1 & 0.02 & 0.18 & - & - & - & - \\
\hline 38 & Phoenix sylvestris (L.) Roxb. & 1.14 & 1.6 & 4.52 & 7.26 & 1.63 & 2.56 & 3.3 & 7.48 \\
\hline 39 & $\begin{array}{l}\text { Pithecellobium dulce (Roxb.) } \\
\text { Benth. }\end{array}$ & 0.72 & 0.8 & 1.92 & 3.43 & 0.6 & 0.71 & 0.05 & 1.35 \\
\hline 40 & Pongamia pinnata (L.) Pierre & 0.36 & 0.4 & 0.83 & 1.59 & 0.06 & 0.09 & 0.01 & 0.17 \\
\hline 41 & Premna latifolia Roxb. & 0.82 & 0.8 & 0.15 & 1.77 & & & & \\
\hline 42 & Prosopis juliflora (Sw.) DC. & 10.02 & 8.99 & 1.04 & 20.06 & 31.63 & 13.77 & 3.31 & 48.72 \\
\hline 43 & Sapindus trifoliatus L. & 0.69 & 1 & 1.31 & 2.99 & - & - & - & - \\
\hline 44 & $\begin{array}{l}\text { Senna siamea (Lam.) H.S.Irwin } \\
\text { \& Barneby }\end{array}$ & 0.2 & 0.3 & 0.84 & 1.34 & 0.03 & 0.09 & 0.08 & 0.2 \\
\hline
\end{tabular}




\begin{tabular}{|c|l|c|c|c|c|c|c|c|c|}
\hline 45 & Strychnos nux-vomica L. & 0.55 & 0.7 & 1.79 & 3.04 & - & - & - & - \\
\hline 46 & Syzygium cumini (L.) Skeels & 0.16 & 0.3 & 0.57 & 1.03 & 0.03 & 0.09 & 0.04 & 0.16 \\
\hline 47 & Tamarindus indica L. & 0.13 & 0.2 & 0.37 & 0.7 & 0.31 & 0.44 & 0.48 & 1.24 \\
\hline 48 & Tectona grandis L.f. & 0.59 & 0.6 & 0.36 & 1.55 & 0.31 & 0.44 & 0.1 & 0.86 \\
\hline 49 & Wrightia tinctoria R.Br. & 1.66 & 2.1 & 0.19 & 3.96 & 3.01 & 3.53 & 0.25 & 6.79 \\
\hline 50 & Ziziphus jujuba Mill. & 8.1 & 9.49 & 1.33 & 18.92 & 12.84 & 14.48 & 1.08 & 28.39 \\
\hline
\end{tabular}

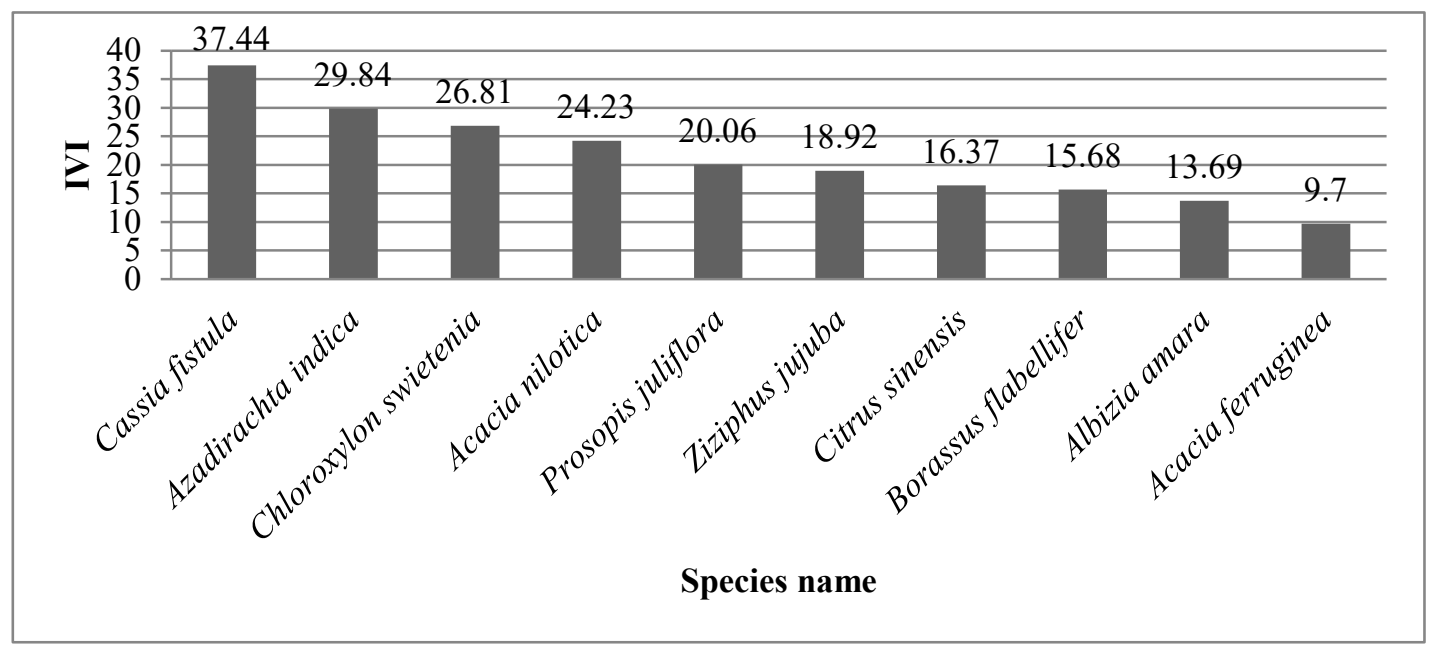

Fig 2: IVI of tree species of Peddagattu Core zone

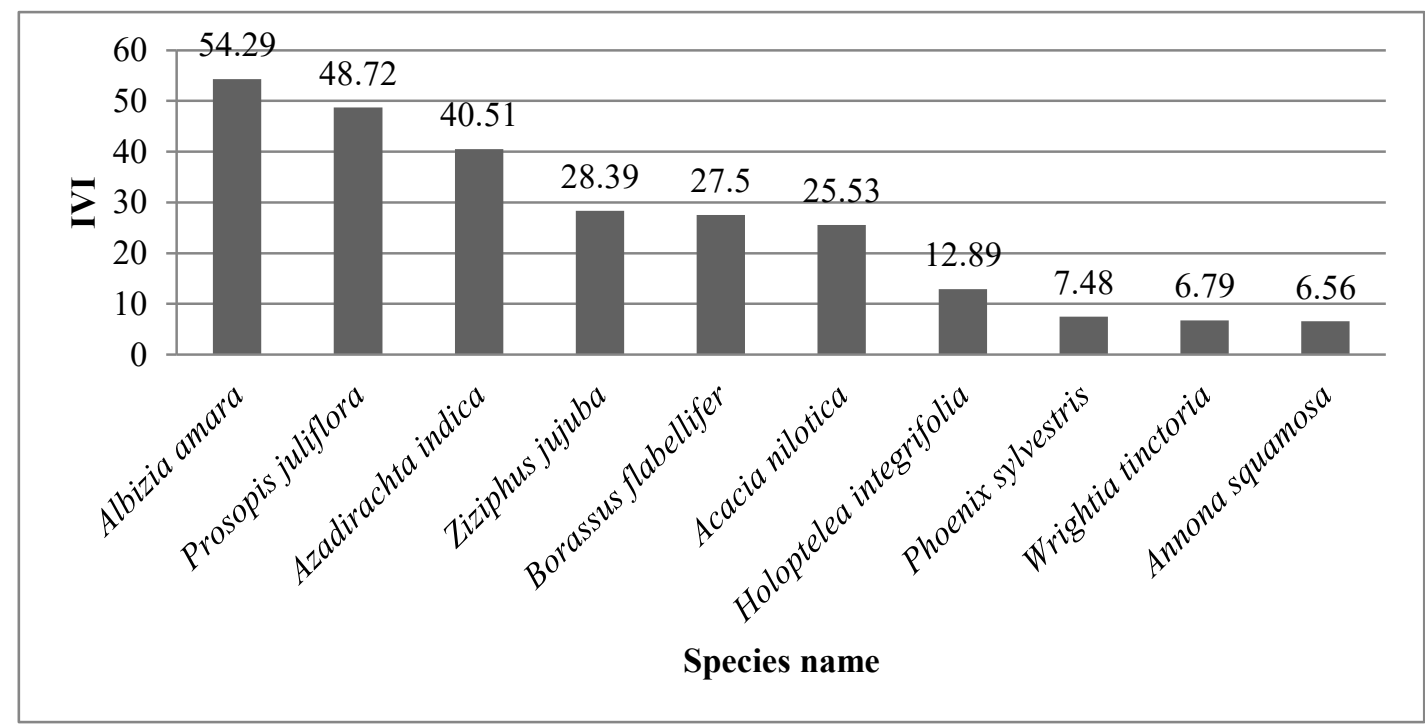

Fig 3: IVI of tree species of Sherepally Core zone

\section{ACKNOWLEDGMENT}

The authors are grateful to Board of Research on Nuclear science (BRNS), BARC, Government of India, for funding the project. We also extended our thanks to Prof. Jayashanker Telangana state Agricultural University (Formerly under Acharya. N. G. Ranga Agricultural University) for granting permission to conduct studies at Peddagattu and Sherepally area, Nalgonda district of Telangana State. 


\section{References}

[1] American Heritage Dictionary. $3^{\text {rd }}$ edition, Houghton Mifflin company (1994).

[2] M.D. Swaine, J.B. Hall and C.J. Alexander. Tree population dynamics Swaziland', Strelitzia 19, South African National Biodiversity Institute, Pretoria (1987).

[3] R. Abdulhadi, E. Mirmanto, and K. A. Kartawinata. A lowland Dipterocarp forest in Sekundur, North Sumatra, Indonesia: Five years after mechanized logging. Proceedings of $3^{\text {rd }}$ Round Table Conference on Dipterocarps, UNESCO (1987).

[4] R. Leslie, Brown, Pieter J. du Preez, Hugo Bezuidenhout, George J. Bredenkamp, H.C. Theo Mostert, B. Nacelle and Collins. Guidelines for phytosociological classifications and Descriptions of vegetation in southern Africa. AOSIS Open Journals. Vol 55 (2013).

[5] S.P. Henzi, L.R. Brown, L. Barrett and A.J. Marais. 'Troop size, habitat use and diet of chacma baboons (Papio hamadyas urisinus) in commercial pine plantations: Implications for management', International Journal of Primatology 32 (2011) 1020-1032.

[6] S.M. Hirst. 'Ungulate-habitat relationships in a South African woodland/savanna ecosystem', Wildlife Monographs 44 (1975) 1-40.

[7] G. Pasternak, L.R. Brown, S. Kienzle, A. Fuller, L.Barrett and S.P. Henzi. 'Population ecology of vervet monkeys in a high latitude, semi-arid riparian woodland', Koedoe 54(1) (2013). http://dx.doi.org/10.4102/koedoe.v54i1.1078.

[8] P.J. Du Preez and L.R. Brown. 'Impact of domestic animals on ecosystem integrity of Lesotho high altitude peatlands' in O. Grillo \& G. Venora (eds.), Ecosystems Biodiversity, Intech, n.p. (2011) 249-270.

[9] A.R. Gotze, S.S. Cilliers, H. Bezuidenhout and K. Kellner. 'Analysis of the vegetation of the sandstone ridges (IB land type) of the north-eastern parts of the Mapungubwe National Park, Limpopo Province, South Africa', Koedoe 50 (2008) 72-81.

[10] B.B. Janecke, P.J. Du Preez and H.J.T. Venter .'Vegetation ecology of the pans (playas) of Soetdoring Nature Reserve, Free State', South African Journal of Botany, 69 (2003) 401-409.

[11] R. Misra. Ecology work book. Oxford and IBH Publishing company Ltd. New Delhi (1968).

[12] P.N. Rao, B.V, Raghava Swamy and T. Pullaiah. Flora of Nalgonda district Andhra Pradesh, India. ShipraPublications (2001).

[13] T. Pullaiah, V. Ramakrishnaiah ,S.Sadhya Rani and P. N. Rao. Flora of Guntur district, Andhra Pradesh, India. Regency Publications (2000).

[14] J.S. Gamble and C. E. C. Fischer. Flora of the Presidency of Madras (1915-1935). repr. ed. 1957. Calcutta.

[15] G. Cottam and J.T. Curtis. "The use of distance measurements in phytosociological sampling" Ecology 37(1956) 451-460.

[16] C.E.Shannon and W. Wiener. The mathematical theory of communication. University of Illinois Press, Urbana 125 (1949).

[17] A.E. Magurran. Ecological diversity and its measurement. Princeton University Press, Princeton, N.J, 179(1988).

[18] E. H. Simpson Measurement of diversity. Nature 163 (1949) 688.

[19] C. Sudhakar Reddy, Chiranjibi Pattanaik, A. Mohapatra and A.K. Biswal. Phytosociological observations on tree diversity of Tropical Forest of Similipal Biosphere Reserve, Orissa, India. Taiwania, 52 (2007) 352-359. 
[20] C. Sudhakar Reddy, Shilpa Babar, Giriraj Amarnath and Chiranjibi Pattanaik. Structure and floristic composition of tree stand in tropical forest in the Eastern Ghats of northern Andhra Pradesh, India. Journal of forestry research, 22(2011) 491-500.

[21] N. Parthasarathy and R. Karthieyan. Biodiversity and population density of woody species in a tropical evergreen forest in Courtallum reserve forest, Western Ghates, India. Tropical Ecology, 38(1997) 297-306.

[22] K. Kaduvul and N. Parthasarathy. Plant biodiversity and conservation of tropical semievergreen forest in the Shervarayan hills of Eastern Ghats, India. Biodiversity and Conservation, 8 (1999) 421-439.

[23] M.E. Martin and J. D. Aber. High spectral resolution remote sensing of forest canopy lignin, nitrogen, and ecosystem processes. Ecology Applications, 7(1997) 431-443.

[24] O.R. Vetaas Gradients in field- layer vegetation on an arid misty mountain plateau in Sudan. Vegetation Science. 3(1992) 527-534.

[25] R. A.S. Sagar, Raghubanshi and J.S.Singh. Tree composition, dispersion and diversity along a disturbance gradient in dry tropical region of India. Forest Ecology and Management. 186(2003) 61-71. 